\title{
Causes of time-transgressive glacial maxima positions of the last Scandinavian lce Sheet
}

\author{
Eiliv Larsen 1,2, Ola Fredin 1,3, Astrid Lyså ${ }^{1}$, Aleksey Amantov ${ }^{4}$, \\ Willy Fjeldskaar ${ }^{5}$ \& Dag Ottesen ${ }^{1}$
}

\author{
${ }^{1}$ Geological Survey of Norway, P.O. Box 6315 Sluppen, N-7491 Trondheim, Norway. \\ ${ }^{2}$ Norwegian University of Science and Technology, Museum of Natural History and Archaeology, N-7491 Trondheim, Norway. \\ ${ }^{3}$ Norwegian University of Science and Technology, Department of Geography, N-7491 Trondheim, Norway. \\ ${ }^{4}$ VSEGEI, Sredny prospect 74, 199106 St. Petersburg, Russia. \\ ${ }^{5}$ Tectonor, P.O. Box 8034, N-4068 Stavanger, Norway.
}

E-mail corresponding author (Eiliv Larsen): eiliv.larsen@ngu.no

Reconstructions of ice cover during the time spanning the Late Weichselian maximum show a confluent Eurasian ice sheet with the Scandinavian Ice Sheet positioned between the Svalbard-Barents-Kara and the British-Irish ice sheets. It has long been suspected among glacial geologists that the maximum ice-marginal position was asynchronous, but only recently has it been possible to explore this in some detail. Dates pertaining to the ice margin of the Scandinavian Ice Sheet reveal an old (29-25 ka) maximum position along its western flank, whereas a younger (18-16 ka) maximum position has been delineated along its eastern flank. A time - distance diagram across the Scandinavian Ice sheet shows an oscillatory western ice front, as opposed to a steadily growing and decaying eastern ice margin. The largest age difference between maximum positions is as much as 10 ka between different sectors of the Scandinavian Ice Sheet. Older maximum positions of the western margin can be explained by its proximity to icegrowth centres, initial windward ice growth, efficient ice drainage in ice streams on the Norwegian continental shelf, and the continental shelf break being a barrier to further westward expansion. Younger maximum positions of the eastern margin can be explained by a very long distance between ice-growth centres and marginal positions, slow flow in a wide zone of cold-based to partly cold-based ice, and punctuated advances of low-gradient ice lobes into proglacial lakes along the extreme eastern perimeter of the ice sheet. The influence of these lakes on the glacier dynamics of adjoining ice lobes prolonged the ice sheet advance by some 1 to 3 ka compared with adjacent interlobate areas.

Keywords: Scandinavian Ice Sheet, asynchronous maximum positions, ice-sheet dynamics, ice-sheet growth, ice-flow velocities

Received 13. November 2015 / Accepted 18. June 2016 / Published online 8. August 2016

\section{Introduction}

The extent of the Eurasian Ice Sheet during the Last Glacial Maximum (LGM) has long been debated (e.g., Denton \& Hughes, 1981; Grosswald, 1998; Svendsen et al., 2004). Ages, however, constraining maximum ice-sheet limits reveal a highly asynchronous ice sheet. This has been common knowledge among glacial geologists, but the difference both in time and in space has been unclear until recently (Böse et al., 2012; Clark et al., 2012; Hughes et al., 2016; Stroeven et al., in press). The consequence is that the Eurasian Ice Sheet was never configured as it is commonly illustrated in numerous conceptual/ overview maps. Until the recent work by Hughes et al. (2016), no LGM reconstruction at full ice-sheet scale has taken this into account by attempting to resolve regional differences in the age of maximum ice-sheet positions. The overall dimensions of the former ice sheet have, thus, been persistently overestimated due to a tendency to correlate maximum ice-marginal positions from one ice sheet sector to another. Refinements to many of these correlations have gone unaddressed, simply because ice-sheet expansion obliterated most traces of previous ice-marginal positions. Accordingly, deglaciation revealed 
widespread geomorphological and sedimentological evidence primarily for those ice-marginal environments postdating the maximum ice-sheet limit, regardless of age differences between different regions.

Dating in recent years of the Scandinavian Ice Sheet (SIS) maximum positions (Fig. 1) has revealed 1) that the age difference between oldest and youngest maximum limits is very large, maybe $\sim 10 \mathrm{ka}$ (Larsen et al., 1999, 2006; Sejrup et al., 2009), and 2) that there are systematic trends in ages of the maximum ice-sheet limit between the western, maritime margin and the eastern, continental margin (Böse et al., 2012; Clark et al., 2012; Hughes et al., 2016).

In this paper, two SIS reconstructions are presented summarising the periods $29-25 \mathrm{ka}$ and $18-16 \mathrm{ka}$, which approximate the maximum limit achieved by the western and eastern sectors of the ice sheet, respectively. As part of the explanation of this age difference, we demonstrate that glacial landforms are distributed differently, but in a systematic manner across the former ice-sheet bed. These trends indicate regional differences in iceflow mechanics and velocities, and signify differences in physical boundary conditions, such as the ice-bed thermal regime and topographic factors controlling rates of ice advance. Thus, much evidence exists relating to how and when the various margins of the SIS achieved their maximum configurations. The main aim of the paper is to examine how regional differences in the physical boundary conditions of the ice sheet can be used to explain the observed west-east asynchrony.

Ages in this paper are based on published radiocarbon dates (calibrated ${ }^{14} \mathrm{C}$ years), cosmogenic nuclide exposure dates $\left({ }^{10} \mathrm{Be}\right)$ and optically stimulated luminescence dates (OSL).

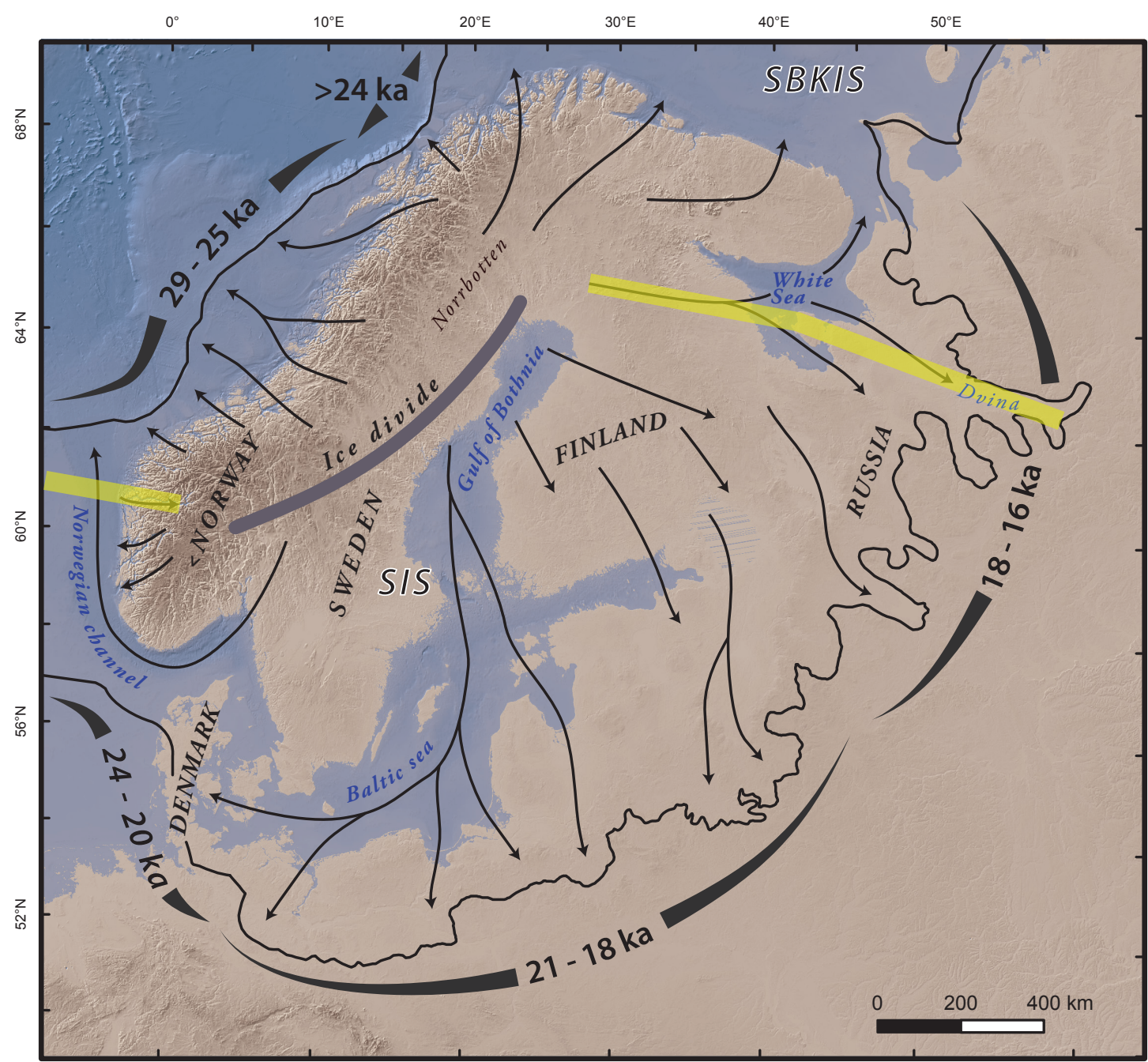

Figure 1. Map showing the LGM maximum extent of the Scandinavian Ice Sheet (SIS) with the Svalbard-Barents-Kara Ice Sheet (SBKIS) to the north and the British-Irish Ice Sheet to the southwest. The reconstruction is according to Svendsen et al. (2004) with modifications in Northwest Russia (Larsen et al., 2014). LGM maximum extent ages for different segments of the ice sheet are based on Larsen et al. (1999, 2006), Lunkka et al. (2001), Vorren \& Plassen (2002), Demidov et al. (2006), Rinterknecht et al. (2006, 2008), Sejrup et al. (2009), Wysota et al. (2009), Jessen et al. (2010), Marks (2012), Böse et al. (2012), Clark et al. (2012), Kalm (2012) and Hughes et al. (2016). Inferred ice-flow trajectories (arrows) are modified from Boulton et al. (2001). Yellow lines are generalisations of the western and eastern sides of the ice sheet in the time - distance diagram (Fig. 3) and the ice-flow synthesis profile (Fig. 8). 


\section{Age and extent of the maximum glaciation}

During maximum Late Weichselian glaciation the SIS calved at the continental shelf break along its western margin. The eastern ice margin ran through Northwest Russia east of the White Sea, continued farther southwestwards to well south of the Baltic Sea, and via Denmark across the North Sea to the southern part of the British Isles (Fig. 1; Svendsen et al., 2004; Hughes et al., 2016). At about the same time as this paper was submitted, the online version of the chronological database and time-slice reconstructions of the last Eurasian Ice Sheet became available (Hughes et al., 2016). The ages of the maxima positions in the different
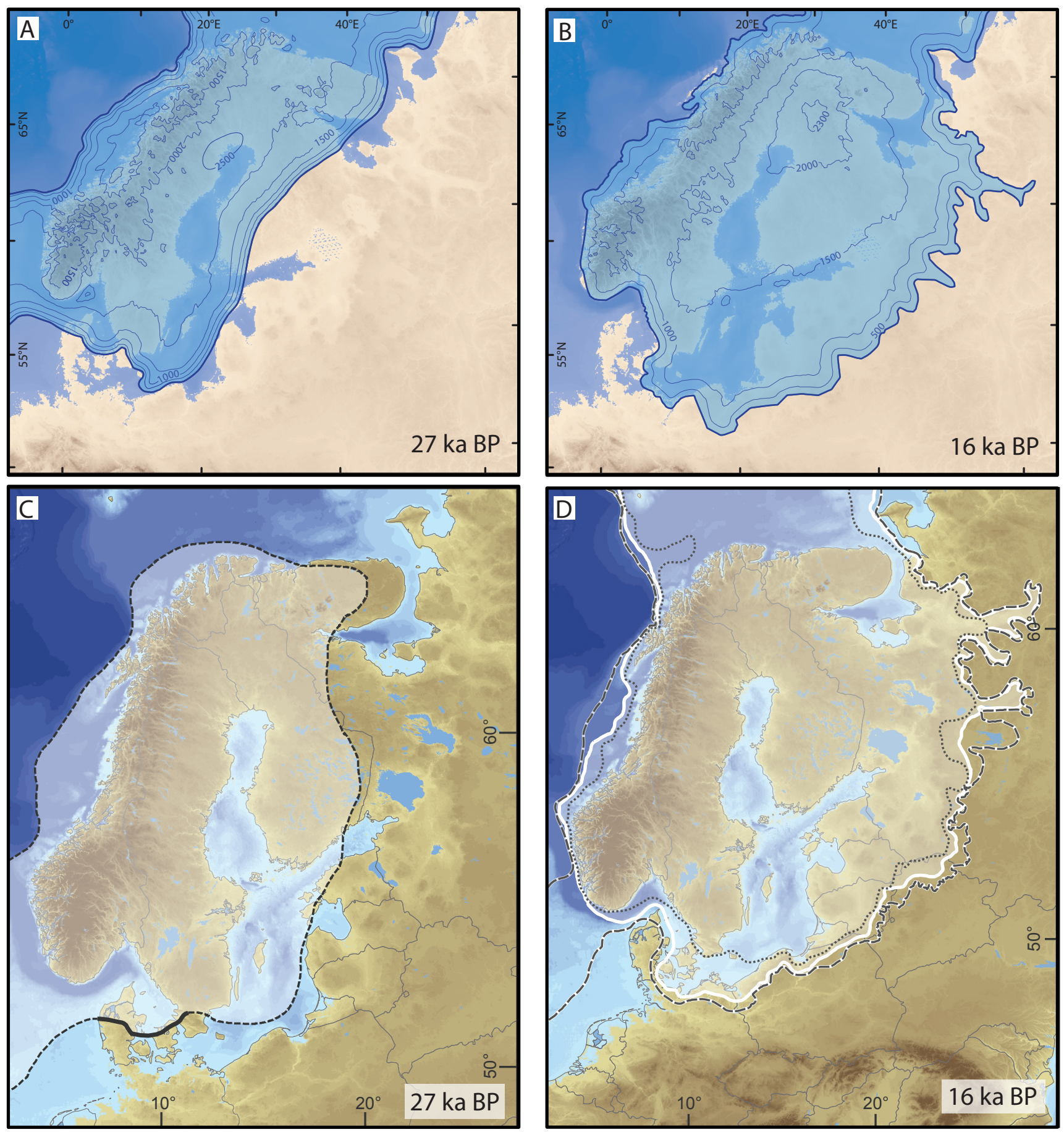

Figure 2. (A-B) Combined mapped and modelled ice-sheet extent and thickness for the Scandinavian Ice Sheet at its southwestern and northeastern maximum positions, respectively. The mapped ice-sheet extents are based on dated maximum ice-marginal positions and stratigraphical information indicating whether or not an area was glaciated. The model is tuned to match these isolines at the given time intervals. Contour interval for ice surface $500 \mathrm{~m}$. (C-D) Reconstructions of the Eurasian Ice Sheet at the time of the southwestern and northeastern maximum positions of the Scandinavian Ice Sheet (Hughes et al., 2016). 
areas follow their comprehensive reconstructions, but areas where large uncertainty or competing hypotheses exist are, nonetheless, discussed below. The differences in inferred maximum ages (Fig. 2), however, have no consequences for the discussion of causes of asynchronous behaviour of the SIS, which is the main purpose of the present paper.

\section{Ages of the maximum positions}

In the river Dvina area of NW Russia (Fig. 1), the maximum Weichselian ice margin was achieved at $c .16 \pm$ $1 \mathrm{ka}$ (Larsen et al., 1999). The large discrepancy between these ages from the eastern margin and those of 26-27 ka constraining the maximum ice-sheet limit on the Norwegian continental margin (Sejrup et al., 1994, 2009) triggered the present study. Of particular interest are uncertainties regarding systematic trends in the ages of maximum ice-sheet limits and potential implications for paleoclimatic reconstructions.

The maximum limit of the ice sheet is oldest west of Britain (26-27 ka; Clark et al., 2012), in the northern North Sea (25-29 ka; Sejrup et al., 2009), and in northern Norway (25-27 ka; Vorren \& Plassen, 2002). The most recently obtained age of the maximum ice-sheet limit west of Svalbard is 23.5-24 ka (Jessen et al., 2010). Dates obtained for the maximum limit of the ice sheet in southern Britain vary between 17 and $25 \mathrm{ka}$, with ages of approximately 23 ka considered most likely (Clark et al., 2012). That is about 3 to 4 ka younger than the age of the maximum position in adjacent maritime areas to the west. The southern to eastern (i.e., continental) SIS maximum margin varies in age from 24 to $16 \mathrm{ka}$, becoming gradually younger from southwest to northeast (Larsen et al., 1999, 2009; Lunkka et al., 2001; Demidov et al., 2006; Rinterknecht et al., 2006, 2008; Wysota et al., 2009; Böse et al., 2012; Marks, 2012).

From these dates, it is evident that the western (maritime) maximum position was reached much earlier than the eastern (continental) maximum. It is also clear that there are regional age differences along the margin (Hughes et al., 2016). The largest age difference between maximum positions may be some 9-11 ka (Fig. 1; Hughes et al., 2016).

\section{Waxing and waning glaciers towards the maxima positions}

In order to better refine ice-marginal positions that predate local maximum ice-sheet limits, stratigraphical observations constraining the timing of previous ice- sheet advances are necessary. Such data provide valuable estimates of past ice-marginal fluctuations that occurred before the ice sheet advanced to its maximum local position. Applying this approach, the reconstructed ice-marginal positions necessarily become generalised and in some instances are inaccurate at a local scale. Nonetheless, this methodology, based on systematic field observations, is considered conceptually more rigorous than previous ice-sheet reconstructions of similar scale.

In their recent compilation, Hughes et al. (2016) reconstructed the evolution of the Eurasian Ice Sheet in a series of time slices from the time of ice inception after the Ålesund Interstadial, some 38-34 ka ago (Mangerud et al., 2010), through subsequent ice-marginal positions and until final deglaciation. Our reconstructions of the ice sheet, during the stages of maximum western and eastern ice-sheet expansion, are shown in Fig. 2A and $\mathrm{B}$, respectively. Corresponding reconstructions from Hughes et al. (2016) are shown in Fig. 2C and D. Our results and those of Hughes et al. (2016) indicate that the ice sheet in the southwest was at its maximum position by some $27 \mathrm{ka}$ ago (Fig. $2 \mathrm{~A}, \mathrm{C}$ ). At that time, the eastern SIS was well inboard from its subsequent maximum position, and it had not yet merged with the SvalbardBarents-Kara Ice Sheet (Fig. 2C). By approximately 16-18 ka (Fig. 2B, D) the SIS had reached its maximum in the Dvina area of NW Russia, but had retreated considerably in many other sectors. Many details, though, are still uncertain between the two extremes in maximum positions (Hughes et al., 2016). For instance, Sejrup et al. (2009) favoured separation of the SIS from the ice sheet over Britain shortly after $27 \mathrm{ka}$. Clark et al. (2012), Svendsen et al. (2015) and Hughes et al. (2016), however, consider the possibility of a long period of sustained confluence between the two ice sheets, but with reduced extent over the North Sea area following a preceding phase of maximum western expansion. Regardless of these uncertainties, the general picture of the southwestern flank of the ice sheet is that of a highly oscillatory ice margin with multiple advances and retreats following early attainment of maximum icesheet limits (e.g., Nygård et al., 2004, 2007; Hubbard et al., 2009; Sejrup et al., 2009; Mangerud et al., 2013; Vorren et al., 2015; Hughes et al., 2016). At the same time, there was steady eastward growth of the ice sheet (Hughes et al., 2016), finally culminating in long, low-gradient ice lobes in NW Russia (Larsen et al., 2014). In Larsen et al. (2010), a volumetric reconstruction of the entire Eurasian Ice Sheets was performed. This reconstruction placed the maximum volume at about $21 \mathrm{ka} \mathrm{BP}$, i.e., in phase with the global maximum (Fig. 3) and with Hughes et al. (2016). The method of estimating ice thickness is described in Amantov \& Fjeldskaar (2013). It consists of establishing averaged values and shapes associated with viscoplastic flow, modification of ice thickness due to subglacial topography, and corrrections for factors like ice streams and variable ice-sheet bed conditions. 


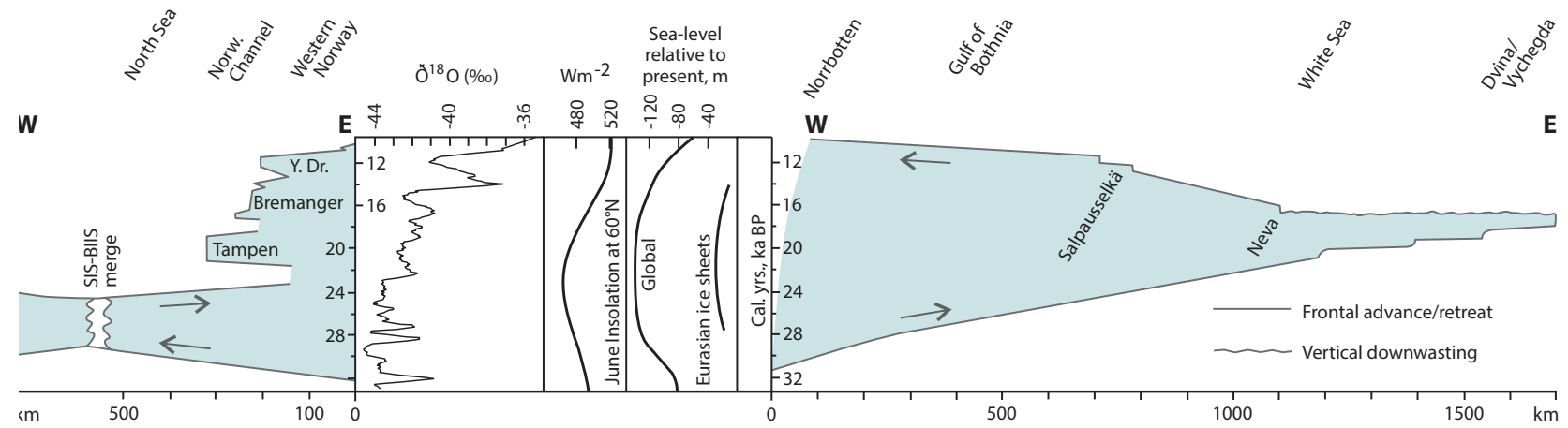

Figure 3. Fluctuations of the margin of the Scandinavian Ice Sheet along two profiles shown as yellow lines in Fig. 1. The western profile is modified from Sejrup et al. (2009) and Mangerud et al. (2013). The eastern profile is based on data in Demidov et al. (2006), Johansson et al. (2011) and Larsen et al. (2014). The time - distance diagrams (ice advances and retreats vs. ages in calibrated kiloyears before present) are compared with: oxygen isotopes $\left(\delta^{18} \mathrm{O}\right)$ from the Greenland ice sheet (Greenland Ice Core Project members, 2004), summer insolation values $\left(\right.$ Watts $\left./ \mathrm{m}^{2}\right)$ at $60^{\circ} \mathrm{N}$ (Berger \& Loutre, 1991), global ice-volume variations in sea-level equivalents (Lambeck et al., 2006) and the contribution of the Eurasian Ice Sheet to global sea level (Larsen et al., 2010).

After the eastern sector of SIS achieved its maximum extent, all parts of the ice sheet decayed, the main exceptions being readvances and stillstands along different sectors of the ice margin during the Younger Dryas (12.8-11.5 ka BP) (e.g., Mangerud et al., 2011). Following the Younger Dryas, deglaciation continued rapidly. By $10 \mathrm{ka}$, the SIS had wasted back to a position close to its inception areas (Hughes et al., 2016). By approximatly $8 \mathrm{ka}$ ago, glaciers in Norway were less extensive than today, and quite likely many were totally gone (Nesje et al., 2008).

The large west-east contrast is shown as a plot of the fluctuating margin through time in a profile across the entire ice sheet (Fig. 3). After the early maximum over southwestern Norway-Britain, the western part of the ice sheet experienced several readvances, but a generally deglacial trend prevailed (Sejrup et al., 2009; Mangerud et al., 2013). At the same time, the ice expanded steadily northeastwards, culminated at the maximum position, and subsequently wasted steadily back. Thus, the westeast contrast comprises both a large difference in age and glacier dynamics.

\section{Glacial inception and ice-flow conditions}

Hughes et al. (2016) suggested a maximum and a minimum version for ice inception in the Scandinavian mountains following the Ålesund Interstadial (38-34 ka; Fig. 4). Their ice inception maximum model is quite similar to an earlier suggestion by Boulton et al. (2001). The minimum model is favoured by Hughes and coworkers, but the data do not allow for an absolute conclusion regarding this (Hughes et al., 2016). Ice sheet growth started after the Ålesund Interstadial (Hughes et al., 2016) which means that it took about $7 \mathrm{ka}$ for ice to grow to its southwestern LGM maximum and yet another $\sim 10 \mathrm{ka}$ to reach the eastern maximum position. It is stressed that a choice between one or the other of the two glacial inception models (Fig. 4) does not inflict on the conclusions regarding causes for the large asynchronous behaviour of the SIS.

The distance from the ice-inception centres in the Scandinavian mountains to the maximum western SIS position is only about one-fourth of that to its eastern counterpart. Thus, the SIS was asymmetric in extent with regard to its ice-inception centres (Fig. 4). The British-Irish Ice Sheet, on the other hand, had iceinception centres located centrally with respect to the maximum margins of the ice sheet. It started to grow at approximately $35 \mathrm{ka}$ BP through merging of small mountain ice caps in the Scottish Highlands (Finlayson et al., 2014).

The substratum upon which glaciers are situated is a significant variable in determining ice-flow mechanisms and velocities. Inside the areas of Caledonide and shield rocks, igneous and metamorphic rocks dominate the Scandinavian peninsula (Fig. 4). The western mountain and fjord areas mainly comprise exposed bedrock. East of the mountains, in Sweden and Finland, thick Quaternary sediment cover is common (Kleman et al., 2008). Along some sections of the eastern SIS margin, ice flow into reverse slopes and against regional fluvial networks caused the former ice front to terminate in proglacial lakes (Fig. 4; e.g., Lyså et al., 2011). This influenced both ice-flow mechanisms and velocities (Larsen et al., 2014), which will be discussed further below.

Glacial landforms and landscapes that have survived previous glaciations are indicators of former subglacial conditions and, thus, are important constraints for past ice flow. Such landforms are shown in Figs. 5 and 6. Mapping of these landforms has shown that they are distributed systematically across the area of the former 


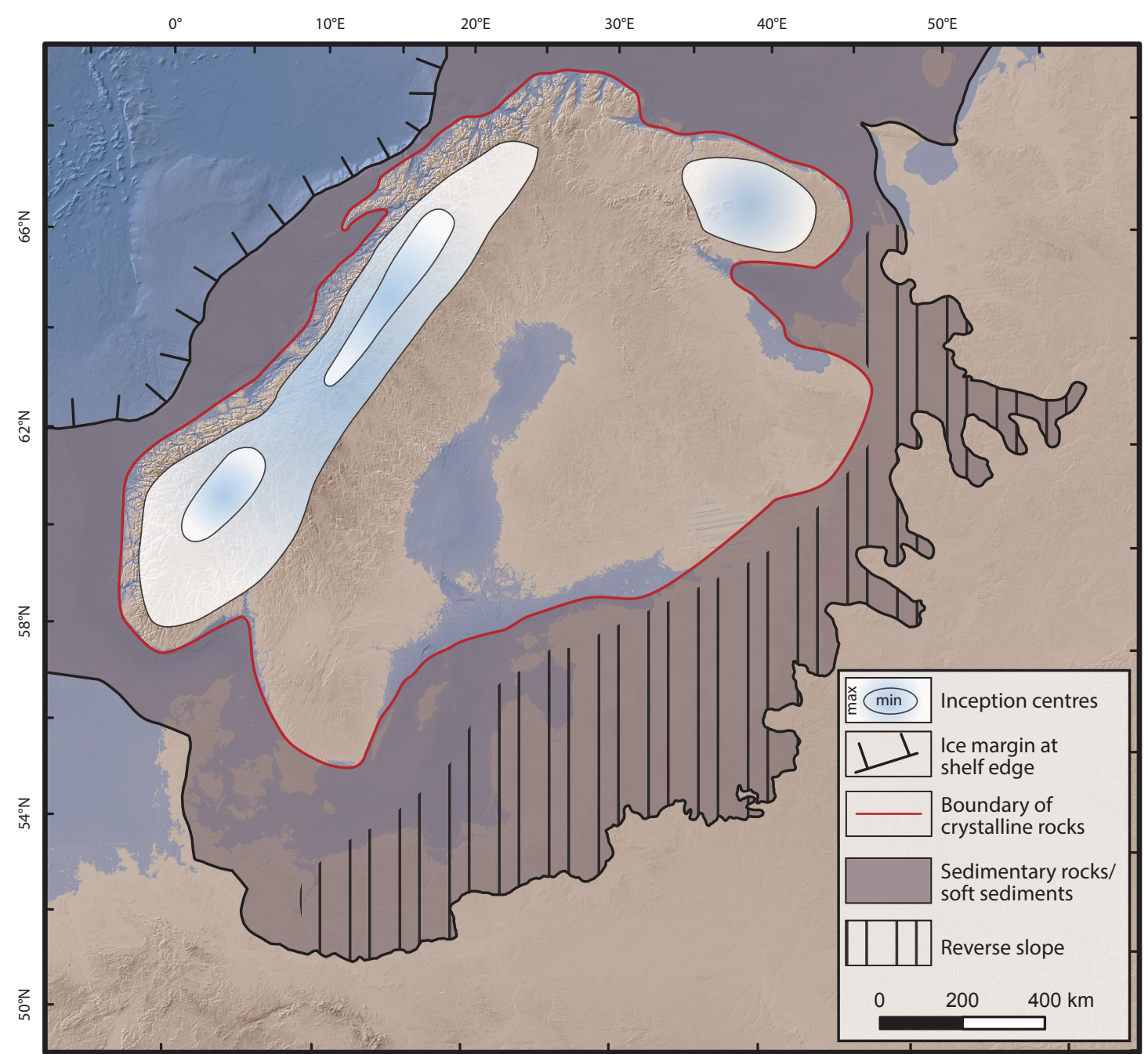

Figure 4. Distribution of 'soft' (sedimentary rocks) and 'hard' (Caledonide and Fennoscandian Shield rocks) according to Kleman et al. (2008) within the glaciated area, and anticipated maximum and minimum scenarios of ice-inception centres (Hughes et al., 2016). The maximum ice-sheet position at the continental shelf break is hatched. Terrain sloping towards the advancing ice is also shown. Note that soft (deformable) sediments are also found in 'hard' rock terrains, most notably east of the Scandinavian mountains (Kleman et al., 2008).

ice-sheet bed (Fig. 7). In the transition zone from hardto soft-bedded substratum on the Norwegian continental shelf, drumlinised features that evolve downstream into megascale glacial lineations (MSGL) are common (Fig. 5A, B). MSGLs are evidence of former ice streams, which occasioned rapid and efficient ice flow (Ottesen et al., 2005a; Andreassen et al., 2008). Between former ice-stream flow paths, on shallower bank areas, such lineations are lacking, suggesting relatively slow ice flow in ice rises (Fig. 7). Closer to former ice-inception centres, on their western side, erosional features of all scales from fjords to striated bedrock dominate (Fig. 5C). Subglacially deposited sediments in these areas are mostly thin and patchy. This is evidence of strong icebed coupling with widespread regelation promoting efficient erosion and downstream subglacial transport of sediment. In areas near former ice divide(s), especially on the eastern side, ribbed (rogen) moraines and relict landscapes are widespread (Fig. 5D, E; Kleman \& Hättestrand, 1999; Kleman et al., 2008), indicating moderate to little erosion over the course of multiple glaciations. Kleman \& Hättestrand (1999) interpreted ribbed moraines to form in the transition zone between ice frozen to its bed and faster-flowing, wet-based ice. Thus, ribbed moraine is indicative of fundamental changes in former ice-flow conditions. Farther east, down-ice from areas of ribbed moraine in Finland and western Russia, extensive drumlin fields are present (Fig. 5F, 6; Larsen et al., 2014). This demonstrates basal sliding and faster ice flow compared with areas of relict landscapes and ribbed moraines farther up-ice. The drumlin fields terminate abruptly to the east, abutting thin to patchy till that extends eastward to the maximum LGM ice margin. Glacial bedforms are almost absent in some valleys, except for a few drumlins occurring outside the deeper parts where weak ice - bed coupling occurred (Larsen et al., 2014). 

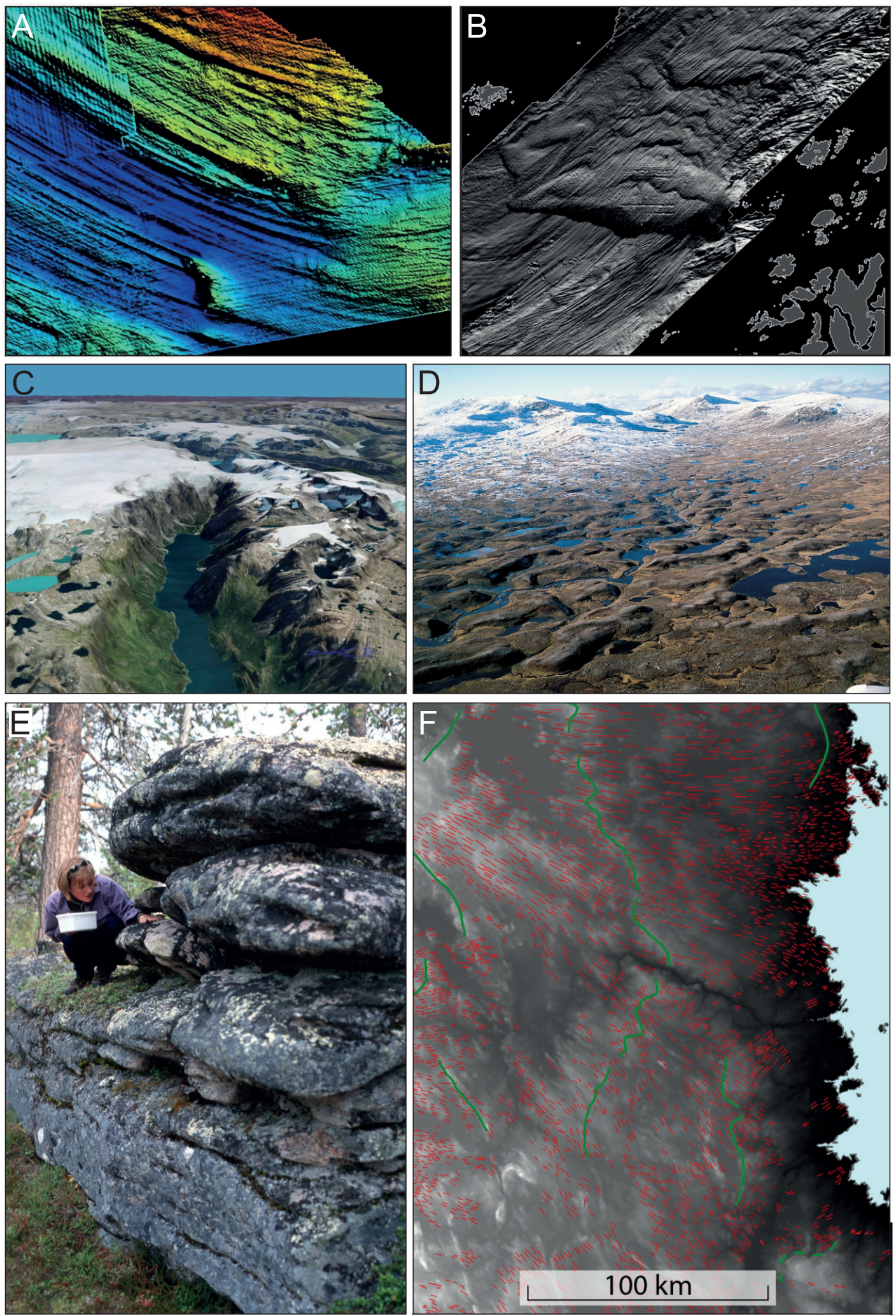

Figure 5. Typical landscape elements across the Scandinavian Ice Sheet. (A-B) Megascale glacial lineations from the Tronadjupet and Vestfjorden area, northern Norway (Ottesen et al., 2005b). (C) Mountainous fjord - valley landscape of northern Norway with the glacier Svartisen in the background (courtesy of Norge i 3D). (D) Ribbed moraine landscape in central Mid Norway just west of the present water divide (Photo: Harald Sveian, Geological Survey of Norway). (E) Tor in the area of relict landscapes, northern Sweden, east of the present water divide. (F) Drumlins and end moraines in Northwest Russia (Fredin et al., 2012; Larsen et al., 2014). 


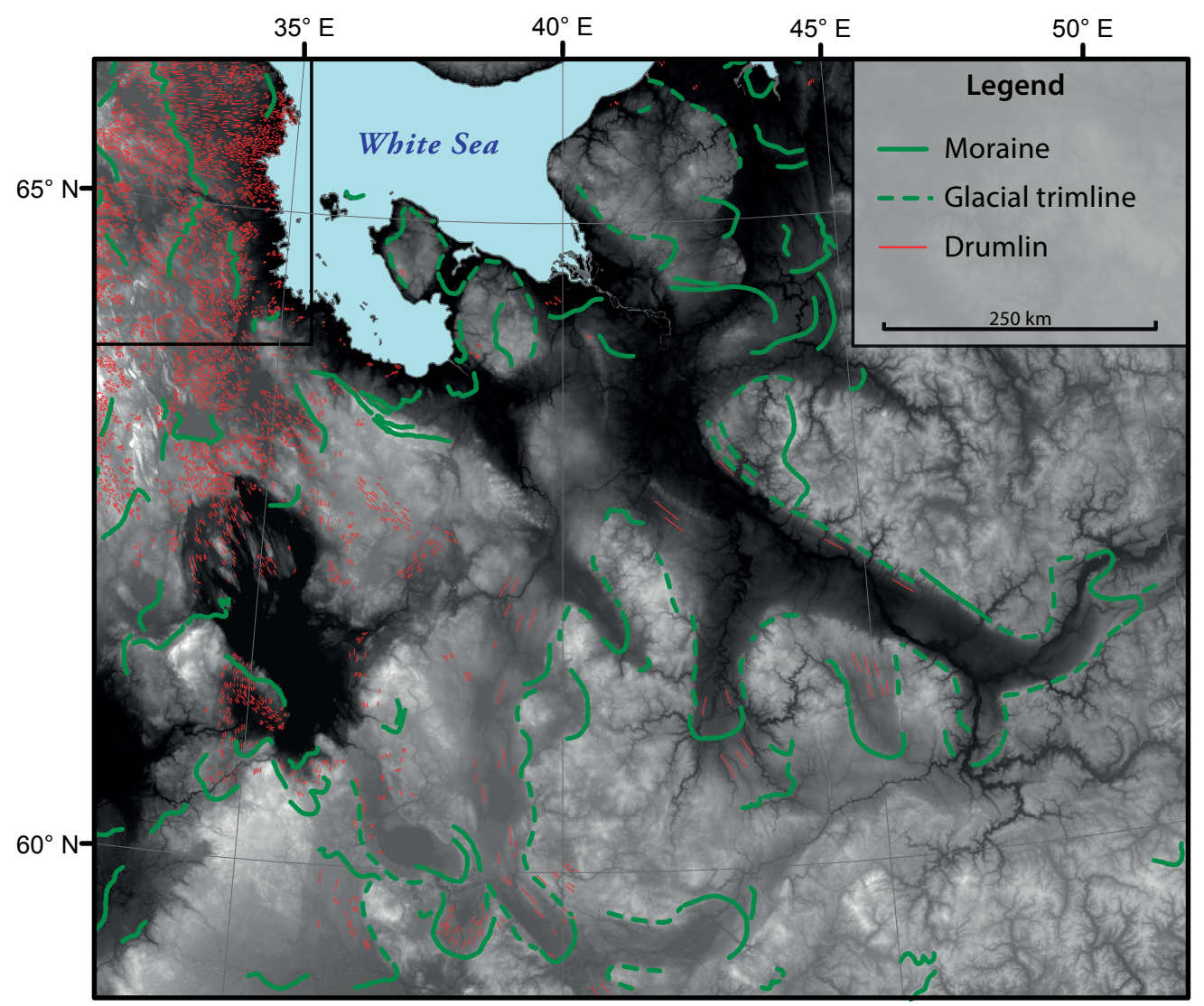

Figure 6. Drumlins, end moraines and glacial trim lines in the White Sea area of northwestern Russia (Fredin et al., 2012; Larsen et al., 2014).

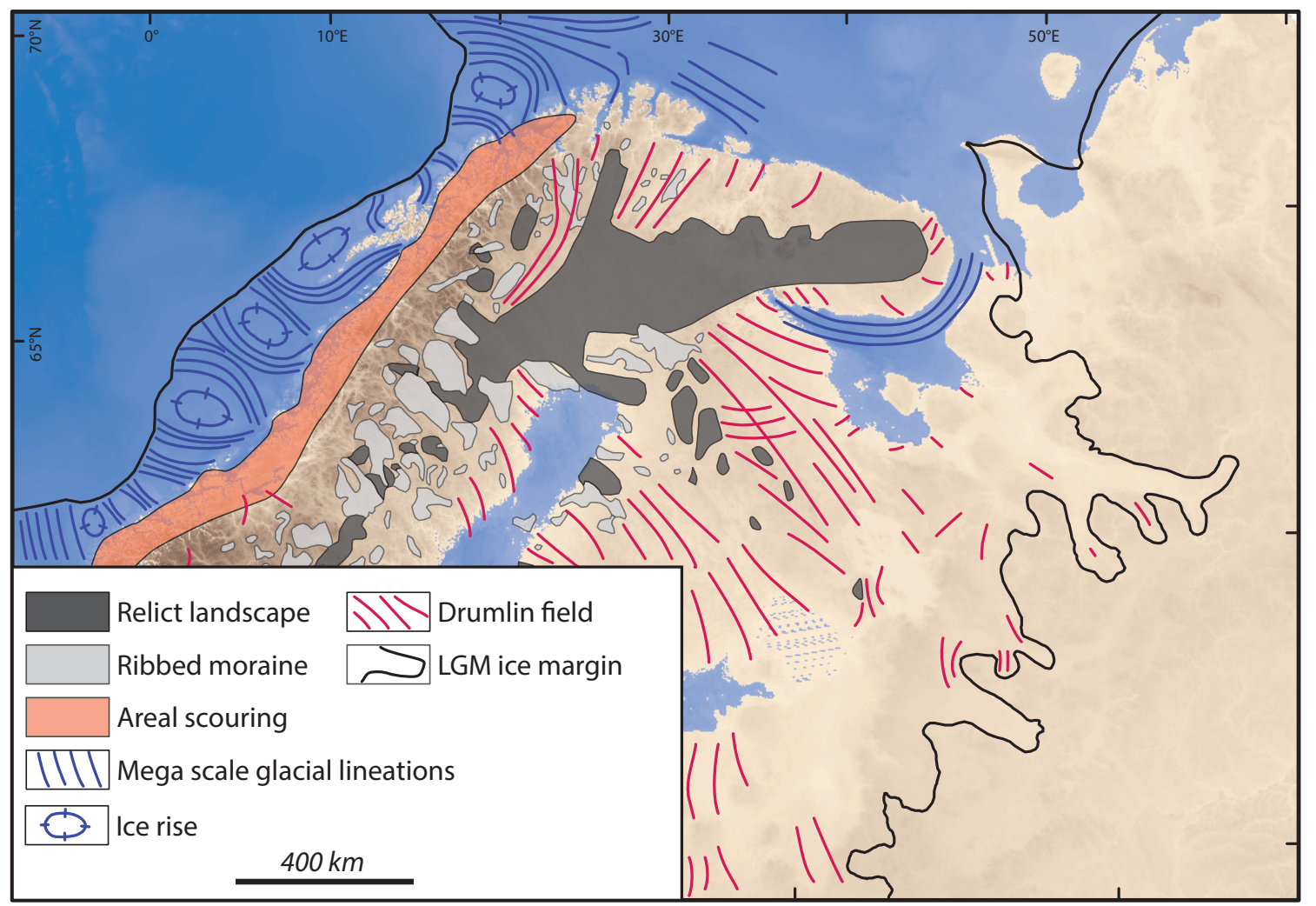

Figure 7. Megascale glacial lineations and ice rises on the continental shelf (Ottesen et al., 2005a; Winsborrow et al., 2010; Bjarnadottir et al., 2014), drumlin fields (Hättestrand \& Clark, 2006; Winsborrow et al., 2010; Fredin et al., 2012; Kalm \& Gorlach, 2014; Larsen et al., 2014, cf. fig. 6), scoured bedrock area west of the present water divide, ribbed moraines and relict landscapes in central areas (Kleman \& Hättestrand, 1999; Kleman et al., 2008) with some additions according to Amantov (1995). 


\section{Causes of asynchronous glacial maxima}

Growth and decay of ice sheets are triggered by climate change, but their evolution pattern is dependent on a number of variables in the physical environment. Fluctuations along the western margin of the SIS are reflected in $\delta^{18} \mathrm{O}$ variations in the Greenland Ice Sheet (Greenland Ice Core Project members, 2004; Mangerud et al., 2013), but eastwards SIS expansion is not (Fig. 3 ). The deglaciation of the entire ice sheet followed increasing values of summer insolation (Berger \& Loutre, 1991). The observed regional differences in the age of maximum ice-sheet margins and the nature of ice flow are likely primarily explained by glaciodynamic responses to geographically variable physical boundary conditions such as topography and the nature of subglacial beds.

Already 70 years ago the concept of maritime, windward growth for continental ice sheets like the Cordilleran and the Scandinavian was developed (Flint, 1943). This was documented further by striations indicating eastward migration of the main SIS ice divide during ice-sheet build-up (Ljungner, 1949). The idea was, to summarise, that there was a highland origin of ice sheets starting with windward accumulation and expansion on the maritime side of the mountains. This was followed by a much slower lee-side growth. Thus, delayed expansion of the SIS to its maximum eastern extent is predicted by this model. It should be noted, though, that it is not completely understood why the ice divide shifted eastwards if the main precipitation sources continued to be in the west.

Glacial sediments and landforms are distributed systematically in a profile across the area of the former ice sheet (Fig. 8), implying spatial variability in subglacial thermal conditions and associated ice-flow mechanisms. The latter is used to infer relative ice-flow velocities of the former ice sheet. Relict landscapes in the mountain areas indicate little subglacial erosion, a wide zone of frozen bed conditions, and ice flow principally through internal deformation. Fringing these areas are widespread occurrences of ribbed moraine. These are interpreted to form in crevasses in the ice in the transition from frozen to thawed bed conditions (Kleman \& Hättestrand, 1999). This implies a down-ice velocity increase as basal sliding becomes more prevalent (Fig. 8). On the western side, the transition to warm-based conditions is indicated by a zone dominated by ice-scoured bedrock in coastal Norway. Farther west, MSGLs were formed under ice streams occupying cross-shelf troughs on the continental shelf. Rapid ice flow was sustained by subglacial sediment deformation along with basal sliding (Nygård et al., 2007). On the eastern side, the area with landforms indicating formerly frozen and partly frozen bed conditions with slow ice flow is much wider than on the western side due to a lower gradient and absence of topographic funnelling (Fig. 8). Thick glacial sediments and extensive drumlin fields farther down-ice on the eastern side show warm-based conditions, flow dominated by basal sliding and accordingly a relative increase in ice-flow velocities. The youngest ages obtained for the maximum ice-sheet position are from northwestern Russia (Larsen et al., 1999; Demidov et al., 2006; Lyså et al., 2014). In this area, the ice sheet was characterised by multiple, long, low-gradient lobes advancing against reverse slopes into proglacial lakes, which occupied the present low-gradient river valleys (Larsen et al., 2014). An overall eastward expansion of the ice sheet was likely characterised by multiple intermittent advances of the ice margin, which were influenced by topographic thresholds promoting ice-marginal stability and proglacial lake basins, facilitating periods of rapid advance when lake levels increased. Thus, former rates and patterns of ice advance were likely dependent on meltwater infilling of proglacial basins. An important consequence of this relationship between proglacial lake levels and ice margins is that the maximum possible lake level determined by continental drainage divides influenced the location of maximum ice-sheet limits in these areas (Larsen et al., 2014). The distance between ice-inception centres and eastern maximum positions is about four times longer than that to maximum positions in the west. This asymmetry was likely enhanced because the ice sheet was calving at the continental shelf break (e.g., Nygård et al., 2007; Vorren et al., 2011), thus prohibiting further westward expansion. These conditions and initial windward glacier growth may chiefly explain the delayed eastern maximum. Furthermore, the differences in glacial flow conditions on either side of the ice divide clearly indicate lower averaged ice-flow velocities in the east compared with the west. This is supported mainly by: 1 ) the very wide zone of frozen to partly frozen bed conditions in the east supporting slow ice flow, and 2) the occurrence of MSGLs indicating fast ice flow in ice streams in crossshelf troughs on the continental shelf to the west (Fig. 8). A special case is the Dvina area in the east where ice lobes achieved a very late maximum extent (Fig. 1). It is inferred that the mechanism by which these lobes advanced into proglacial lakes (as discussed above) promoted delayed maximum positions. Comparing the youngest maximum ages with those in adjoining areas (Fig. 1), it is suggested that the delay was in the order of 1 to $3 \mathrm{ka}$. Following this, we conclude that the topography in the east helped facilitate ice-sheet advances far up river valleys, whereas the opposite was the case in the west, where the shelf break was a topographic barrier to further expansion. A similar argument was used to explain why the seaward maximum position of the British-Irish Ice Sheet was some 4 ka older than its landward margin in southern England (Clark et al., 2012). Compared with this, we find the time lag of up to some 10 ka reasonable for the much larger and asymmetric SIS. 


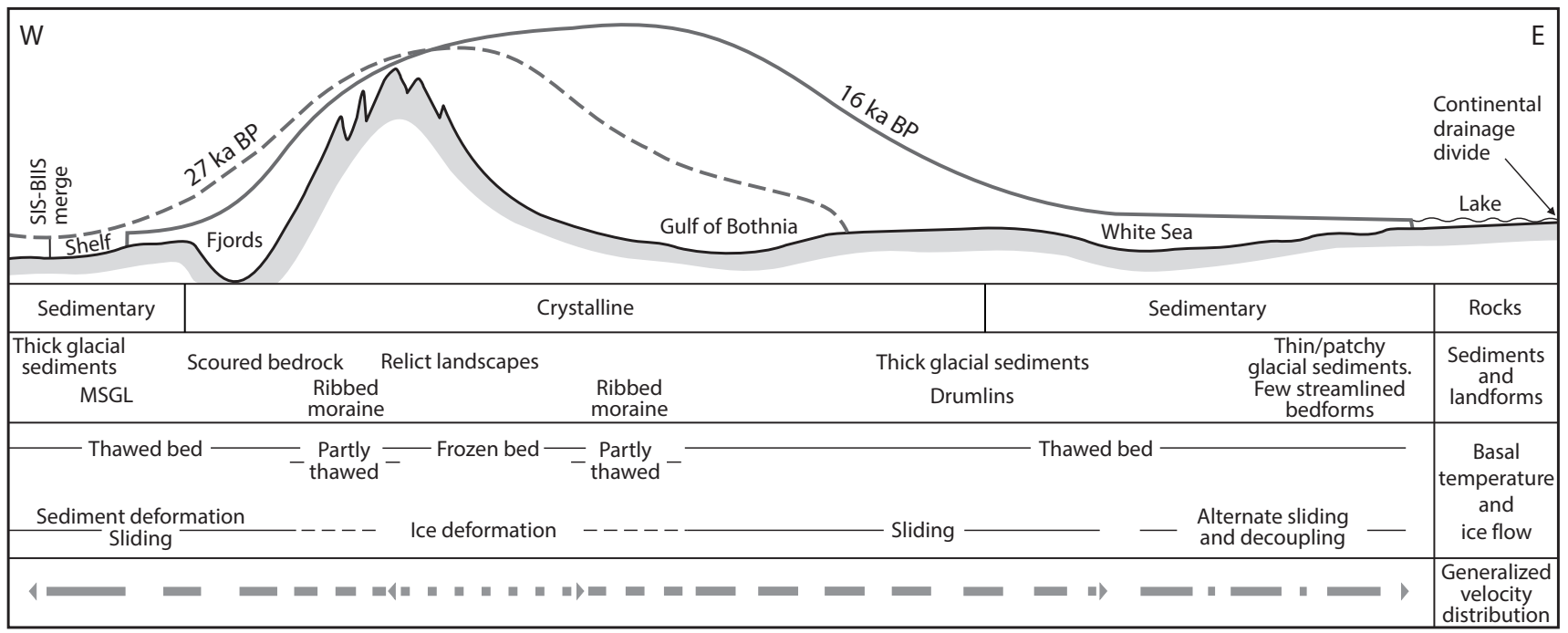

Figure 8. Simplified terrain profile across Scandinavia with the western glacial maximum with the Scandinavian Ice Sheet (SIS) and the British Irish Ice Sheet (BIIS) merging at $27 \mathrm{ka} \mathrm{BP}$, and with the eastern maximum at $16 \mathrm{ka}$, both drawn as simplified glacier profiles. Generalised distribution of bedrock, sediments and landforms, subglacial thermal conditions, ice-flow mechanisms, and relative ice-flow velocities are shown along the same profile.

\section{Conclusions}

New reconstructions of the configuration of the Scandinavian Ice Sheet and a synthesis of dates constraining former maximum ice-marginal positions during the Late Weichselian glaciation have revealed:

- An old ( 27 ka BP) maximum position in the southwestern part of the SIS compared with its northeastern counterpart with an age of 18-16 ka BP. When the northeastern maximum was attained, the southwestern part of the ice sheet was greatly reduced in extent.

- The old western maximum age can be explained by short distances to ice-inception centres, initial windward ice-sheet growth, efficient drainage in ice streams on the Norwegian continental shelf, and the continental shelf break being a barrier to further westward expansion.

- The young maximum age on the eastern side can be explained by a four times greater distance between ice-inception centres and maximum ice-marginal positions, low ice-flow velocities mostly by internal deformation in a wide zone east of the ice divide, and low-gradient ice-lobe advances controlled by successive glacier-damming and meltwater-infilling of sub-basins within regional fluvial networks.

- The inferred ice-flow mechanism for the easternmost ice lobes prolonged the ice advance by some 1 to $3 \mathrm{ka}$ compared with adjoining interlobate areas.

- The lobe advances against reverse slopes and into proglacial lakes suggest that the unglaciated continental drainage divide influenced the maximum position of the eastern SIS.

Acknowledgements. This paper is a contribution to the IPY SciencePub project no. $175937 /$ S30, funded by the Research Council of Norway (NFR), and to the GLACIPET project no. 169291, financed by the NFR's PETROMAKS program and Statoil. Irene Lundquist provided some of the artwork. Thomas Lakeman, and the journal referees Anna Hughes and Adrian Hall are thanked for constructive comments. The choice of topic was influenced by Russian customs authorities and the Russian secret police (FSB), as the first and third authors on their way to the field area were held back, charged with espionage and subsequently expelled from Russia. This aborted our work in Russia, and we had to do something else instead, like write this paper.

\section{References}

Amantov, A. 1995: Plio-Pleistocene erosion of Fennoscandia and its implication for the Baltic area. Proceedings of the Third Marine Geological Conference "The Baltic". Prace Państwowego Institutu Geologicznego CXLIX, 47-56.

Amantov, A. \& Fjeldskaar, W. 2013: Geological-geomorphological features of the Baltic region and adjacent areas: imprint on glacial-postglacial development. Regional Geology and Metallogeny, St.Petersburg, Russia 53, 90-104.

Andreassen, K., Laberg, J.S. \& Vorren, T.O. 2008: Seafloor geomorphology of the SW Barents Sea and its glaci-dynamic implications. Geomorphology 97, 157-177.

Berger A. \& Loutre M.F. 1991: Insolation values for the climate of the last 10 million years. Quaternary Sciences Reviews 10, 297-317.

Bjarnadóttir, L.R., Winsborrow, M.C.M. \& Andreassen, K. 2014: Deglaciation of the central Barents Sea. Quaternary Science Reviews 92, 208-226.

Böse, M., Lüthgens, C., Lee, J.R. \& Rose, J. 2012: Quaternary glaciations of northern Europe. Quaternary Science Reviews 44, 1-25.

Boulton, G.S., Dongelmans, P., Punkari, M. \& Broadgate, M. 2001: Palaeoglaciology of an ice sheet through a glacial cycle: the European 
ice sheet through the Weichselian. Quaternary Science Reviews 20, 591-625.

Clark, C.D., Hughes, A.L.C., Greenwood, S.L., Jordan, C. \& Sejrup, H.P. 2012: Pattern and timing of retreat of the last British-Irish Ice Sheet. Quaternary Science Reviews 44, 112-146.

Demidov, I.N., Houmark-Nielsen, M., Kjær, K.H. \& Larsen, E. 2006: The Last Scandinavian Ice Sheet in northern Russia: ice flow patterns and decay dynamics. Boreas 35, 425-443.

Denton, G.H. \& Hughes, T.J. (eds.) 1981: The Last Great Ice Sheets. Wiley-Interscience, New York, 484 pp. pp.

Finlayson, A., Fabel, D., Bradwell, T. \& Sugden, D. 2014: Growth and decay of a marine terminating sector of the last British - Irish Ice Sheet. A geomorphological reconstruction. Quaternary Science Reviews 83, 28-45.

Flint, R.F. 1943: Growth of the North American ice sheet during the Wisconsin Age. Geological Society of America Bulletin 54, 325-362.

Fredin, O., Rubensdotter, L., van Welden, A., Larsen, E. \& Lyså, A. 2012: Distribution of ice marginal moraines in NW Russian Federation and Eurasia. Journal of Maps. doi: 10.1080/17445647.2012.708536.

Greenland Ice Core Project members 2004: High-resolution record of Northern Hemisphere climate extending into the last interglacial period. Nature 431, 147-151.

Grosswald, M.G. 1998: Late-Weichselian ice sheets in Arctic and Pacific Siberia. Quaternary International 45/46, 3-18.

Hättestrand, C. \& Clark, C.D. 2006: The glacial geomorphology of Kola Peninsula and adjacent areas in the Murmansk Region, Russia. Journal of Maps 2006, 30-42.

Hubbard, A., Bradwell, T., Golledge, N.R., Hall, A.M., Patton, H., Sugden, D.E., Cooper, R. \& Stoker, M.S. 2009: Dynamic cycles, ice streams and their impact on the extent, chronology and deglaciation of the British-Irish ice sheet. Quaternary Science Reviews 28, 758-776.

Hughes, A.L.C., Gyllencreutz, R., Lohne, Ø.S., Mangerud, J. \& Svendsen, J.I. 2016: The last Eurasian ice sheets - a chronological database and time-slice reconstruction, DATED-1. Boreas 45, 1-45. doi: 10.1111/bor.12142.

Jessen, S.P., Rasmussen, T.L., Nielsen, T. \& Solheim, A. 2010: A new late Weichselian and Holocene marine chronology for the western Svalbard slope 30,000 - 0 cal years BP. Quaternary Science Reviews 29, 1301-1312.

Johansson, P., Lunkka, J.P. \& Sarala, P. 2011: The Glaciation of Finland. In Ehlers, J., Gibbard, P.L. \& Hughes, P.D. (eds.): Quaternary Glaciations - Extent and Chronology; A Closer Look, Developments in Quaternary Science 15, Elsevier, Amsterdam, The Netherlands, pp. 105-116.

Kalm, V. 2012: Ice-flow pattern and extent of the last Scandinavian ice sheet in the southeast of the Baltic Sea. Quaternary Science Reviews $44,51-59$.

Kalm, V. \& Gorlach, A. 2014: Impact of bedrock surface topography on spatial distribution of Quaternary sediments and on the flow pattern of late Weichselian glaciers on the East European Craton (Russian Plain). Geomorphology 207, 1-9.

Kleman, J. \& Hättestrand, C. 1999: Frozen-bed Fennoscandian and Laurentide ice sheets during the Last Glacial maximum. Nature 404, 63-66.

Kleman, J., Stroeven, A.P. \& Lundqvist, J. 2008: Patterns of Quaternary ice sheet erosion and deposition in Fennoscandia and a theoretical framework for explanation. Geomorphology 97, 73-90.

Lambeck, K., Purcell, A., Funder, S., Kjær, K.H., Larsen, E. \& Möller, P. 2006: Constraints on the Late Saalian to early Middle Weichselian ice sheet of Eurasia from field data and rebound modeling. Boreas $35,539-575$.

Larsen, E., Lyså, A., Demidov, I., Funder, S., Houmark-Nielsen, M., Kjaer, K.H. \& Murray, A.S. 1999: Age and extent of the Scandinavian ice sheet in northwest Russia. Boreas 28, 115-132.

Larsen, E., Kjær, K.H., Demidov, I.N., Funder, S., Grøsfjeld, K., Houmark-Nielsen, M., Jensen, M., Linge, H. \& Lyså, A. 2006: Late Pleis- tocene glacial and lake history of northwestern Russia. Boreas 35, 394-424.

Larsen, N.K., Knudsen, K.L., Krohn, C.F., Kronborg, C., Murray, A.S. \& Nielsen, O.B. 2009: Late Quaternary ice sheet, lake and sea history of southwest Scandinavia - a synthesis. Boreas 38, 732-761.

Larsen, E., Andreassen, K., Fjeldskaar, W., Sejrup, H.P., Cyr, I., Haflidason, H., Hjelstuen, B.O.B., Jensen, M., Knies, J., Laberg, J.S., Lyså, A., Løtveit, I.F., Nygård, A., Riis, F. \& Viola, R. 2010: Ice ages. Subsidence, uplift and tilting of traps - the influence on petroleum systems. GlaciPet final report. Norges geologiske undersøkelse Report 2010.11, 117 pp.

Larsen, E., Fredin, O., Jensen, M., Lyså, A., Kuznetsov, D. \& Subetto, D. 2014: Subglacial sediment, proglacial lake level and topographic controls on ice extent and lobe geometries during the Last Glacial Maximum in NW Russia. Quaternary Science Reviews 92, 369-387.

Ljungner, E. 1949: East-west balance of the Quaternary ice caps in Patagonia and Scandinavia. Bulletin of the Geological Institution of the University of Uppsala 33,11-96.

Lunkka, J.P., Saarnisto, M., Gey, V., Demidov, I. \& Kiselova, V. 2001: Extent and age of the Last Glacial Maximum in the southeastern sector of the Scandinavian Ice Sheet. Global and Planetary Change $31,407-425$.

Lyså, A., Jensen, M., Larsen, E., Fredin, O. \& Demidov, I.N. 2011: Icedistal landscape and sediment signatures evidencing damming and drainage of large pro-glacial lakes, northwest Russia. Boreas 40, 481-497.

Lyså, A., Larsen, E., Buylaert, J.-P., Fredin, O., Jensen, M., Kuznetsov, D., Murray, A., Subetto, D. \& van Welden, A. 2014: Late Pleistocene stratigraphy and sedimentary environments of the Severnaya Dvina - Vychegda region in northwestern Russia. Boreas 43, 759779 .

Mangerud, J., Gulliksen, S. \& Larsen, E. 2010: ${ }^{14} \mathrm{C}$-dated fluctuations of the western flank of the Scandinavian Ice Sheet 45-25 kyr BP compared with Bølling-Younger Dryas fluctuations and DansgaardOescher events in Greenland. Boreas 39, 328-349.

Mangerud, J., Gyllenkreutz, R., Lohne, Ø.S. \& Svendsen, J.I. 2011: Glacial history of Norway. Developments in Quaternary Science 15, 279-298.

Mangerud, J., Goehring, B.M., Lohne, Ø.S., Svendsen, J.I. \& Gyllencreutz, R. 2013: Collapse of marine-based outlet glaciers from the Scandinavian Ice Sheet. Quaternary Science Reviews 67, 8-16.

Marks, L. 2012: Timing of the Late Vistulian (Weichselian) glacial phases in Poland. Quaternary Science Reviews 44, 81-88.

Nesje, A., Bakke, J., Dahl, S.O., Lie, Ø. \& Matthews, J.A. 2008: Norwegian mountain glaciers in the past, present and future. Global and Planetary Change 60, 10-27.

Nygård, A., Sejrup, H.P., Haflidason, H., Cecchi, M. \& Ottesen, D. 2004: The deglaciation history of the southwestern fennoscandian Ice Sheet between 15 and $13{ }^{14} \mathrm{C}$ ka. Boreas 33, 1-17.

Nygård, A., Sejrup, H.P., Haflidason, H., Lekens, W.A.H., Clark, C.D. \& Bigg, G.R. 2007: Extreme sediment and ice discharge from marinebased ice streams: New evidence from the North Sea. Geology 35, 395-398.

Ottesen, D., Dowdeswell, J.A. \& Rise, L. 2005a: Submarine landforms and the reconstruction of fast-flowing ice streams within a large Quaternary ice sheet: the 2500-km-long Norwegian-Svalbard margin (57o-80oN). Geological Society of America Bulletin 117, 10331050.

Ottesen, D., Rise, L., Knies, J., Olsen, L. \& Henriksen, S. 2005b: The Vestfjorden-Trænadjupet palaeo-ice stream drainage system, midNorwegian continental shelf. Marine Geology 218, 175-189.

Rinterknecht, V.R., Clark, P.U., Raisbeck, G.M., Yiou, F., Bitinas, A., Brook, E.J., Marks, L., Zelcs, V., Lunkka, J.-P., Pavlovskaya, I.E., Piotrowski, J.A. \& Raukas, A. 2006: The Last Deglaciation of the Southeastern Sector of the Scandinavian Ice Sheet. Science 31, 1449-1452.

Rinterknecht, V.R., Bitinas, A., Clark, P.U., Raisbeck, G.M., Yiou, 
F. \& Brook, E.J. 2008: Timing of the last deglaciation in Lithuania. Boreas 37, 426-433.

Sejrup, H.P., Haflidason, H., Aarseth, I., King, E., Forsberg, C.F., Long, D. \& Rokoengen, K. 1994: Late Weichselian glaciation history of the Northern North Sea. Boreas 23, 1-13.

Sejrup, H.P., Nygård, A., Hall, A.M. \& Haflidason, H. 2009: Middle and late Weichselian (Devensian) glaciation history of south-western Norway, North Sea and eastern UK. Quaternary Science Reviews 28, 370-380.

Stroeven, A.P., Hättestrand, C., Kleman, J., Heyman, J., Fabel, D., Fredin, O., Goodfellow, B.W., Harbor, J.M., Jansen, J.D., Olsen, L., Caffee, M.W., Fink, D., Lundqvist, J., Rosqvist, G.C., Strömberg, B. \& Jansson, K.N. In press: Deglaciation of Fennoscandia. Quaternary Science Reviews. doi: 10.1016/j.quascirev.2015.09.016.

Svendsen, J.I., Alexanderson, H., Astakhov, V.I., Demidov, I., Dowdeswell, J.A., Funder, S., Gataullin, V., Henriksen, M., Hjort, C., Houmark-Nielsen, M., Hubberten, H.W., Ingolfsson, O., Jakobsson, M., Kjaer, K.H., Larsen, E., Lokrantz, H., Lunkka, J.P., Lyså, A., Mangerud, J., Matiouchkov, A., Murray, A., Moller, P., Niessen, F., Nikolskaya, O., Polyak, L., Saarnisto, M., Siegert, C., Siegert, M.J., Spielhagen, R.F. \& Stein, R. 2004: Late Quaternary ice sheet history of northern Eurasia. Quaternary Science Reviews 23, 1229-1271.
Svendsen, J.I., Briner, J.P., Mangerud, J. \& Young, N.E. 2015: Early Break-up of the Norwegian Channel Ice stream during the Last Glacial Maximum. Quaternary Science Reviews 107, 231-242.

Vorren, T. \& Plassen, L. 2002: Deglaciation and palaeoclimate of the Andfjorden-Vågsfjord area, North Norway. Boreas 31, 97-125.

Vorren, T.O., Landvik, J.Y., Andreassen, K. \& Laberg, J.S. 2011: Glacial History of the Barents Sea Region. In Ehlers, J., Gibbard, P.L. \& Hughes, P.D. (eds.): Quaternary Glaciations - Extent and Chronology; A Closer Look, Developments in Quaternary Science 15, Elsevier, Amsterdam, The Netherlands, pp. 361-372.

Vorren, T.O., Rydningen, T.A., Baeten, N.J. \& Laberg, J.S. 2015: Chronology and extent of the Lofoten - Vesterålen sector of the Scandinavian Ice Sheet from 26 to 16 cal. ka BP. Boreas 44, 445-458. Winsborrow, M.C.M., Andreassen, K., Corner, C.D. \& Laberg, J.S. 2010: Deglaciation of a marine-based ice sheet: Late Weichselian palaeoice dynamics and retreat in the southern Barents Sea reconstructed from onshore and offshore glacial geomorphology. Quaternary Science Reviews 29, 424-442.

Wysota, W., Molewski, P. \& Sokolowski, R.J. 2009: Record of the Vistula ice lobe advances in the LateWeichselian glacial sequence in northcentral Poland. Quaternary International 207, 26-41. 